\section{Cattle Climate \\ Calamity}

Abhinav Bhati, Medha
Gupta and Eileen Zhao

Grade 10 Science

The Woodlands Secondary

School

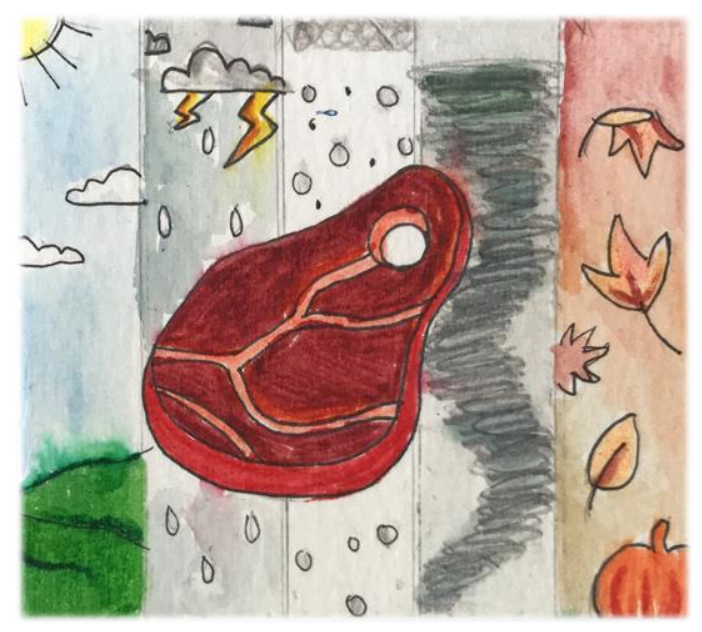

\section{Abstract}

Cows are one of the biggest contributors to climate change. Cattle produce a lot of methane from flatulence and eructation due to their ruminant stomachs. Human consumption of beef has exponentially increased the cattle population and therefore, putting more methane into the atmosphere. This study looks at how vegan and/or vegetarian diets can be more accessible to the general public in hopes of promoting more sustainable living. At the Woodlands Secondary School in Mississauga we sampled out various vegan and/or vegetarian recipes to spread the word and teach our peers that alternative diets can be just as tasty!

\section{Introduction}

Climate change is a change in the usual weather patterns found in a place. Climate change resulting from cattle farming may be catastrophic for many countries unless we, as a society, do not stop (or significantly reduce) cattle farming and other activities that emit greenhouse gases. Humans also release carbon into the air by cutting trees, burning fossil fuels, etc. Because of all these human activities, there is $42 \%$ more carbon in the atmosphere now, than there was before the industrial era (David Suzuki Foundation, 2019).

Canada ranks among the world's top 10 per capita consumers and exporters of beef. Canada's beef-cow herd is estimated at approximately 5 million head (Thecanadianencyclopedia.ca, 2019). Beef is a staple in many people's diets. As a very common protein, people tend to be very reluctant to alter their diets. But imagine the change that would occur if people replaced the beef in their diets with more sustainable and less resource intensive proteins and foods.

\author{
I found this topic very \\ interesting because I have \\ been vegetarian my entire \\ life and listening to people's \\ inquiries about my diet \\ really highlights this issue. \\ Questions like where I get \\ my protein from and what \\ kind of food I eat are very \\ common. \\ -Medha
}


"This was quite shocking to find out. I didn't realize just how much cattle farming contributed to climate change" -Abhinav

"I found this piece of information to be quite shocking, because when people think of climate change, the first thing to come to mind is carbon dioxide."

- Eileen

The hardest part of collecting responses was getting unbiased and legitimate responses. As we targeted youth, we had to make sure to survey people from many different backgrounds, age ranges, genders, etc. -Medha

"The hardest part was communicating over phone with the various cooking schools. Some responses were extremely vague." - Abhi
Cattle produce a lot of methane from flatulence and eructation due to their ruminant stomachs. Human consumption of beef has exponentially increased the cattle population and therefore, putting more methane into the atmosphere.

Methane is 23 times more potent than carbon dioxide and is the second most consequential greenhouse gas. Each cow produces $100 \mathrm{~kg}$ of methane per year and there are approximately 1.6 billion cows in the world, therefore there are approximately 160 billion $\mathrm{kg}$ of methane being released into the atmosphere per year. That means that 1 cow is equivalent to 1000 litres of petrol being burned (Timeforchange.org, 2019). That is a very significant amount, and if people were able to alter that, then hopefully humans can change the course of climate change and save our planet.

So how can society change the course of climate change by encouraging people to alter their diets?

\section{STUDY}

A survey was conducted, asking 31 participants, mainly middle to high school students, about their knowledge of climate change in relation to cattle farming, their beef consumption and how likely they would be to alter the amount of beef they consume. The main focus of our survey was to determine if participants' knowledge of climate change impacted their willingness to alter their beef consumption. See Figure 2 (next page).

Our primary research also involved contacting 5 cooking schools to determine whether or not they offer vegan and/or vegetarian cooking lessons in the

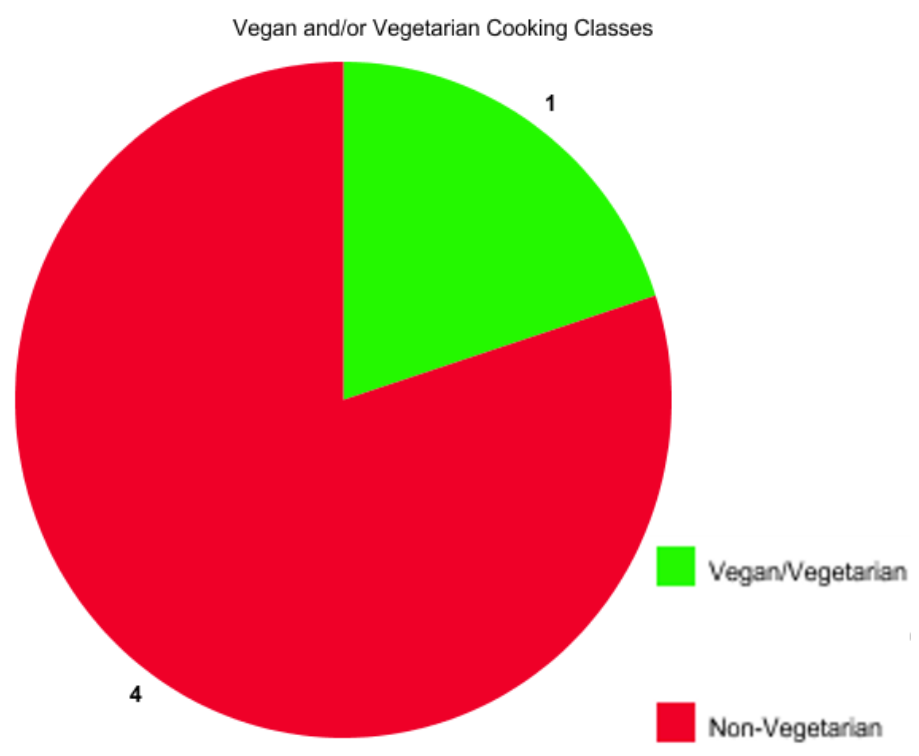

Figure 1: Number of vegan and/or vegetarian cooking lessons offered in the GTA 
GTA. Our focus was to determine the availability of vegan and/or vegetarian cooking lessons compared to meat-based cooking lessons. We wanted to see the convenience of accessing alternative meal options for the general public. See Figure 1.
Number of People Aware That Cows Produce Methane

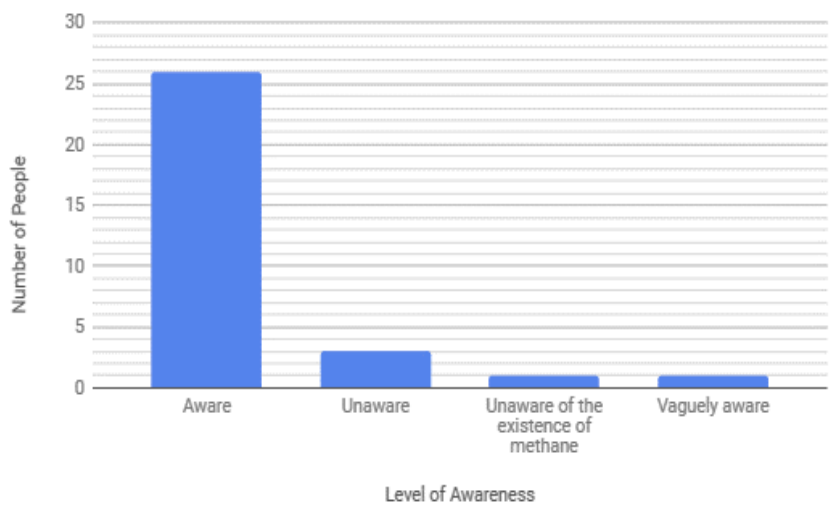

Figure 2: Number of participants who claimed to be aware of methane production from cattle.

\section{Results Summary}

Out of the 31 participants, 26 individuals claimed they were aware that cattle farming produces methane, with 5 participants who were unaware. Out of the 31 participants, 3 individuals said they would completely give up consuming beef. Out of the 5 cooking schools contacted, 1 offered vegan and/or vegetarian cooking lessons.

\section{Discussion}

Though this study was likely not representative of the participants' perspectives on the situation discussed in the introduction of the article, it was made clear that the participants were aware of climate change but were not willing to alter their meat consumption. We hypothesized that this may be due to the lack of knowledge and skills preparing vegan and/or vegetarian meals.

\section{Taking Action}

Vegan and/or vegetarian diets can greatly reduce methane emissions into the atmosphere, and thus, reduce human impact on climate change. Our study showed that participants are aware of the impact their diet may have on climate change, but resist change due to difficulties in accessing vegan and/or vegetarian recipes. We used social media platforms (Twitter, Instagram and YouTube) to our advantage by sharing various recipes and offering vegan and/or vegetarian cooking lessons. We also brought in samples of various recipes to have our peers sample vegan/vegetarian dishes. Our social action was to focus on making vegan and/or vegetarian cooking lessons more easily accessible, to promote a more sustainable diet for a more sustainable future.

We need to target both youth and older generations. Targeting youth presents some issues, as they are not the grocery decision makers. Therefore, targeting parents and/or older generations may be more impactful.

\section{- Eileen}




\section{References}

"Global warming." Britannica School, Encyclopedia Britannica, 22 Oct. 2018.

school.eb.com/levels/high/article/global-warming/37044. Accessed 4 Dec. 2018.

"Methane." Assets.publishing.service.gov.uk, www.assets.publishing.service.gov.uk/government/uploads/system/uploads/attachment data/file/318 336/hpa Methane General Information v1.pdf. Accessed 9 Dec. 2018.

Fellows, University of Houston Energy. "Methane Is A Powerful Greenhouse Gas, But Where Does It Come From?" Forbes, Forbes Magazine, 12 Oct. 2017, www.forbes.com/sites/uhenergy/2017/09/29/methane-is-a-powerful-greenhouse-gas-but-where-doesit-come-from/\#59996f305912. Accessed 8 Dec. 2018.

"Alessandro Volta - Discoverer of Methane." World of Chemicals â Online Chemical Directory, Chemistry Portal, Articles, News, Worldofchemicals, 18 Feb. 2013, www.worldofchemicals.com/171/chemistryarticles/alessandro-volta-discoverer-of-methane.html. Accessed 8 Dec. 2018.

Key facts and findings. (n.d.). Retrieved from http://www.fao.org/news/story/en/item/197623/icode/

"Methane." Pollutant Fact Sheet, www.apps.sepa.org.uk/spripa/Pages/Substancelnformation.aspx?pid=65. Accessed 9 Dec. 2018.

Maclachlan, Ian R. and E. Stringham. "Beef Cattle Farming". The Canadian Encyclopedia, 17 December 2016, Historica Canada. https://www.thecanadianencyclopedia.ca/en/article/beef-cattle-farming. Accessed 08 December 2018.

Steinfeld, H., Gerber, P., Wassenaar, T., Castel, V., Rosales, M. and de Haan, C. (2006). LIVESTOCK'S LONG SHADOW. [ebook] Rome: Chief, Publishing Management Service. Available at: http://www.fao.org/docrep/010/a0701e/a0701e00.pdf [Accessed 8 Dec. 2018].

"General Statistics." General Statistics | Beef Farmers of Ontario, Farm and Food Care Ontario, 2017, www.ontariobeef.com/industry/general-statistics.aspx. Accessed 08 December 2018.

"Cattle Farming In Canada". BCSPCA, 2018, https://spca.bc.ca/programs-services/farm-animalprograms/farm-animal-production/beef-cattle/. Accessed 8 Dec 2018.

Pariona, Amber. "Biggest Farms In The World." WorldAtlas, 25 Apr. 2017, www.worldatlas.com/articles/biggest-farms-in-the-world.html. Accessed 8 Dec 2018.

E360 Digest. "Americans Who Accept Climate Change Outnumber Those Who Don't 5 to 1." Yale Environment 360, Yale School of Forestry \& Environmental Studies, 18 Apr. 2018, 